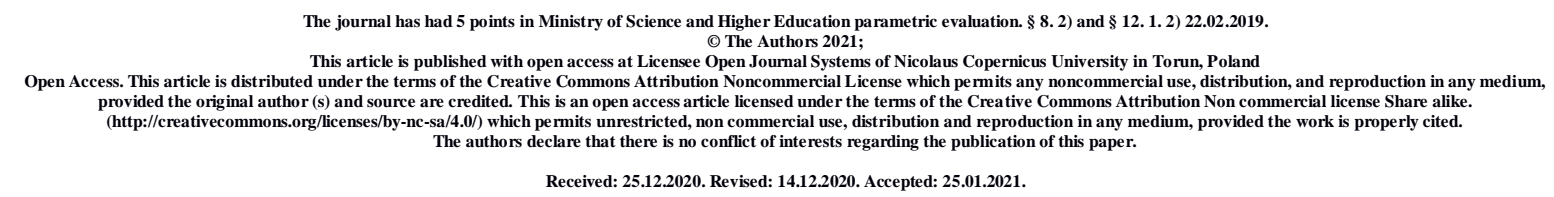

UDK [378.07:005.336.4]:3581.851(477)

\title{
HISTORICAL ASPECTS OF PUBLIC ADMINISTRATION IN EDUCATION OF UKRAINE
}

\section{Inna Mykhailivna Shorobura}

\author{
Khmelnytskyi Humanitarian Pedagogical Academy, Ukraine \\ Rector, Doctor of Pedagogical Sciences, Professor, \\ orcid.org/0000-0003-3728-7968
}

\begin{abstract}
The article covers the historical aspects of public administration in education of Ukraine. The process of transition to another form of education administration was difficult and extended, as there was no experience, conditions and challenging socio-political situation in the country complicated the process. The powers of public self-government bodies are defined by special laws and constituent documents. The combination of state and public administration in education creates public administration that proclaims the priority of the state with the obligatory consideration of public opinion.
\end{abstract}

Key words: public administration; education of Ukraine; historical aspects. 


\title{
ІСТОРИЧНІ АСПЕКТИ ДЕРЖАВНО-ГРОМАДСЬКОГО УПРАВЛІННЯ В ОСВІТІ УКРАЇНИ
}

\author{
Шоробура Інна Михайлівна
}

\section{Хмельницька гуманітарно-педагогічна академія, Україна}

Ректор, доктор педагогічних наук, професор, orcid.org/0000-0003-3728-7968

У статті висвітлюються історичні аспекти державно-громадського управління освітою України. Процес переходу до іншої форми управління в освіті був складним і тривалим, адже не було досвіду, умов, складна соціально-політична ситуація в країні утруднювали процес. Повноваження органів громадського самоврядування визначено спеціальними законами та установчими документами. Поєднання державного i громадського управління в освіті створює державно-громадське управління, яке проголошує пріоритет держави з обов'язковим урахуванням громадської думки.

Ключові слова: державно-громадське управління; освіта України; історичні аспекти.

Formulation of the problem... Changes in the socio-political structure of our country determine a new educational policy which is aimed at building a democratic, legal state and meeting the educational needs of the citizens of independent Ukraine. The implementation of public education policy based on democratic procedures of self-government and cogovernment is a requirement of today. The analysis of scientific research shows a significant interest of the authors in public administration in education.

Analysis of recent research and publications... The issues of public administration are considered in the works of V. Andrushchenko, S. Honcharenko, D. Dzvinchuk, I. Ziaziun, V. Kremen, V. Luhovyi and others. Some aspects of the educational institutions' activities are described in the works of E. Berezniak, V. Bochkarev, L. Haievska, V. Hrabovskyi, D. Deikun, M. Komarnytskyi, V. Kniazev, T. Shamov and others. Such scholars as T. Butyrska, V. Hrabovskyi, S. Krysiuk, T. Lukina, A. Mazak and others discuss some features of public administration.

The purpose of the article is to analyze some historical aspects of public administration development within education of Ukraine. 
Research results... The issue of administration has always been in the focus of researches. Today we must understand the historical aspects of the public administration development. Thus, L. Haievska in her thesis tries to provide the periodization of education administration. According to the scholar, the 1 period (1860-1865) is the emergence of the elements of public administration (reorganization of the Ministry of Public Education, redistribution of powers, creation of collegial public administration in education, adoption of new documents); 2 period (1865-1880) includes counter-reforms and implementation of centralization in education [3]. The further periods introduced by L. Haievska coincide with those singled out by researcher N. Fedorova. [15].

We should note that V. Husarov identifies the following periods of the public administration formation: 1 period (1860-1917) - pre-revolutionary; 2 period (1917-1990) soviet; 3 period (1991 - present) - post-perestroika [4].

O. Pastovenskyi referes to the periodization as well, noting that during the period of 20s of the twentieth century the Soviet school was open. And the period of 1931-1991 he defines as total centralization of the education system and the formation of state administration in education. The scholar remarks, that the 90-ies of the XX century -2014 is the period of emergence and development of regional administration in education within independent Ukraine [13].

In general, democratic governance values in Ukraine is a national trait, which roots go back deep into history. Thus, once a teacher for a village was selected by the whole community: after the Liturgy, parents and other citizens, using questions, evaluated moral character and knowledge of the applicant, and only then entered into an employment contract [2].

Ivan Franko also mentioned the harm of authoritarian administration and the need for its democratization. “...A good teacher, - he said, - should be put in such conditions, so that he could do something good... for this purpose there should be less officers over the teacher, because if he is supervised by ten different authorities: the viit, the priest, the members of the local school council, the inspector and the school district council, the lord, the tenant, and the gendarme..., even if he was the most capable and sincere, he would not get along. For the school property supervision, - said Ivan Franko, - there should be a local school committee, and for the science supervision - a district inspector... This would give the teacher a certain independence, without which his job is often only hard work" [16].

The ideas of democratization of administration were further approved. Thus, between the First and Second World Wars in Galicia "Pedagogical Circles", prototypes of school 
councils, were quite common. They were organized by "Ridna Shkola" society. It is known that priests, artisans, intellectuals and active representatives of youth were involved in the "Pedagogical Circles". The participation of teachers was insignificant. One of the main functions of such "circles" was financial - they cared for better school conditions, looked after the children from poor families, supported teachers [2, C. 16-19].

During the twentieth century in the Soviet Union, which included Ukraine, there was an administrative-command, planned-centralized model of education administration. This meant that the entire educational sector was strictly subordinated to government and totally dependent on the state financially. All administration was centralized and required complete subordination of the lower levels to the higher. Even then nobody denied the influence and participation of the public administration in education, but at that time both state and local authorities were under control and acted according to instructions.

At the end of the twentieth century this idea became even more widespread. Autonomy has become almost the main form of democracy in the educational institutions. There have been dozens of alternative forms of administration in the history of education (councils for the promotion of public education, councils of people's deputies, councils of socio-pedagogical complexes, councils on military and patriotic education, councils of the public, councils of educational institutions, councils of school friends, councils of parents, councils of affairs, boards of trustees, headquarters, patrons' councils), but all of them were usually theoretical in nature. The exceptions were pedagogical councils, methodological associations of teachers and parent committees, which were effective. The most common at that time were school councils, which included students, parents and teachers in equal proportions. The academic councils of higher education institutions included students. We should also mention the boards of trustees, which in the early 90s of the twentieth century arose at schools and functioned in accordance with their statutes, performing an advisory function. The formation of bilateral interaction between the state and the publicity was started earlier, which gave the opportunity to public institutions and individual citizens to join the formation and implementation of educational policy. [2].

Since Ukraine gained its independence, management approaches began to transform and public participation in the education sector was seriously discussed. Thus, in 1991 Ukraine adopted the Law "On education", where Article 10 declares that "a system of public administration is being created in Ukraine to manage education". According to Article 16 of this law, public self-government in education includes general meeting (conference) of the 
educational institution staff; district, city, regional conferences of pedagogical staff, AllUkrainian congress of educators [8].

Public self-government in education submit proposals regarding educational policy and, within its competence and according to the law, address educational, research, methodological, economic and financial issues. The State National Program "Education" ("Ukraine: XXI Century"), adopted in 1993, along with the main tasks of reforming the education system states the need to "overcome the monopoly position of the state in education", which means transition from state to public administration and distribution of functions between central, regional and local education authorities [5].

According to the National Doctrine of Education Development approved in 2002, "state policy in the field of education is aimed at strengthening the role of local self-governing authorities, enhancing involvement of parents, boards of trustees, philanthropists, public organizations, foundations, media in educational, scientific and methodological, economic activity of educational institutions, forecasting their development, assessing the quality of educational services" [12]. At the time, public councils are created, members of the public are introduced into the boards of the committees, educational districts are formed, that is, the powers of public administration are gradually expanding. Thus, it may be affirmed that the transition from the traditional system of education administration to the public one started when Ukraine declared its independence and gradually increased.

In 2008 under the aegis of the Academy of Educational Sciences of Ukraine, the Encyclopaedia of Education was published, which defines the concept of public education administration as a governance that combines the activities of governmental units of state and public administration and is based on the principles of the delegation of authorities and public involvement in education administration [6].

The process of transition to another form of education administration was difficult and extended, as there was no experience, conditions and challenging socio-political situation in the country complicated the process.

As of today, public administration in education combines at its core administrative activity of state administrative bodies, public self-governing authorities and members of the general public. Each of these bodies, without any exception, has its own powers and performs certain functions in this process. This form of administration significantly minimizes the participation of the state and limits its functions, reducing them to the development of national educational policy and ensuring the rights and guarantees of everyone in receiving an 
education. It is the duty of the members of the general public to take an active part in constituting the educational policy.

To implement the policy of public administration in education, several tasks that would gradually reform the process of the governance in this field, were set, namely: decentralization and redistribution of functions and powers of administrative bodies at the national, regional and local levels; strengthening the role of public bodies in education administration; restriction of the influence of state administrative bodies in the activities of educational institutions and increasing their independence; promoting the formation of public responsibility, participation, democratic culture, the ability to analyse and forecast.

Thus, the way out is to apply in education administration one of the types of selfgovernment - public self-government. The Law of Ukraine "On Education" defines this concept as follows - public self-government in the field of education - is the right of the participants of educational process and public associations, other civil society institutions, the constituent documents of which provide for activities in education and / or social protection of persons with special educational needs, to address the issues in the field of education both directly and through public self-government bodies, to participate in the administration of educational institutions, local and state affairs in the field of education on issues that fall within their authority.

The powers of public self-government bodies are defined by special laws and constituent documents of educational institutions, but they may also exercise other rights that are not prohibited by law. Most commonly, they put forward proposals on the formation of state policy in the field of education and, within their powers, address issues of educational, research and methodological, economic, and financing and operating activity of educational institutions. According to the same law, the activities of public self-government and public administration in the field of education are carried out on the principles of: priority of human and civil rights and freedoms; rule of law; mutual respect and partnership; representativeness of public self-government bodies, public associations and other civil society institutions and the legal competence of their representatives; the obligation to consider parties' suggestions; priority of conciliation procedures; transparency, openness and publicity; the obligation to comply with the reached agreements and the mutual responsibility of the parties [14].

Thus, public administration in education is often understood as the process of combining multidirectional activities of state and public management entities in the interests of man, society, government, and its subject is coordination and focus of efforts of different by nature and direction authorities on the development of educational system. 
The main advantage of this type of administration is that it is considered to be the best possible way to meet the demands and interests of participants in the educational process in the flow of balanced interaction between the public and government bodies. It is important to put emphasis on the balanced combination in the public administration of national regulations and individual social initiatives and the determining role of the latter as a factor contributing to decentralization $[7,11]$.

According to $\mathrm{V}$. Bochkarov, distinctive features of public education administration are: the presence of a state structure of education administration, in which each management entity is granted with specific authorities and responsibilities; the existence of a public structure of education administration, all management entities of which are granted with real authorities and responsibilities; coordinated distribution of powers and responsibilities between state and public entities in education administration at all levels; agreed by the bodies of state and public education administration system to settle differences and disputes that may arise between them [1].

Analysing the content of public administration in education, L. Haievska [3] identifies the advantages and disadvantages of state and public components. The researcher describes the following advantages of the state component: ideological and resource base and the practice of administrative management, which ensures maximum efficiency of the educational sphere. In general, the advantages of the public component include: independence of selfgovernment actions in joint administration; broad social basis for public participation in coadministration and activities of educational institutions; the experience of open and public discussion and making decisions; encouraging initiative; considering the opinion of the minority. The disadvantages of the public component are: potential lack of resources and opportunities to finance development projects; insufficient level of competence of participants [3].

The researcher describes the following disadvantages of the state component: authoritarianism of administerial position; bureaucracy in taking and implementation decisions; reliance on administrative regimes and pressure on civil society institutions, attempts to limit their role and reduce their importance; tendencies to increase the administration structure; use of state resources in the process of defining and implementation educational policy; adherence to the hierarchy of power; rejection of the minority position. The essence of public administration in modern education involves coordinated interaction between the state and the community in addressing various issues of education, connected 
with the ability responsibly and effectively influence educational policy, making administrative decisions, creating a healthy social environment [11].

It should be noted that public administration in education is defined as the integration of three areas of work: democratization of state administrative bodies and education administration; development of self-governing associations of participants in educational activities; organization of public education administrative bodies, where all social groups are represented [10].

\section{Conclusions and directions for further research...}

The combination of state and public administration in education creates public administration that proclaims the priority of the state with the obligatory consideration of public opinion. Further research is needed on public administration issues in higher education institutions.

\section{References}

1. Bochkarev, V. Y`. Koncecy`ya gosudarstvenno-obshhestvennogo upravleny`ya obshhy`m obrazovany`em Rezhy`m dostupa: http://www.doxa.ru/obr/ sobranie/Conf1.htm

2. Vy`shnevs`ky`j O. Posy`lennya roli gromads`kosti v upravlinni shkil`noyu osvitoyu yak dominuyucha skladova procesu rozderzhavlennya shkoly`. Upravlinnya osvitoyu. 2015. \#16. S. 16-19.

3. Gayevs`ka L.O. Rozvy`tok derzhavno-gromads`kogo upravlinnya zagal`noyu seredn `oyu osvitoyu v Ukrayini (druga polovy`na XIX pochatok XX st.): avtoref. dy`s... d-ra nauk z derzh. upr.: specz. 25.00.01 - «Teoriya ta istoriya derzhavnogo upravlinnya» Ky`yiv, 2010. 39 s.

4. Gusarov V.I. Gosudarstvenno-obshhestvennoe obrazovany`e: monografy`ya. Samara: Y`zd-vo «NTCz», 2006. 420 s.

5. Derzhavna nacional’na programa «Osvita» (Ukrayina XXI stolittya). K.: Rajduga, 1994.

6. Ency`klopediya osvity` / Akad. ped. nauk Ukrayiny`; golov. red. V.G. Kremen`. K.: Yurinkom Inter, 2008. 1040 s. S. 179-180.

7. Zadorozhny`j G.V. Social’ne partnerstvo - real`ny`j shlyax do vidkry`togo suspil`stva. X.: XIBM, 2000. $192 \mathrm{~s}$.

8. Zakon Ukrayiny` «Pro osvitu» [Vidomosti Verxovnoyi Rady`URSR (VVR), 1991, \# 34, st. 451). [Elektronny j resurs] - Rezhy`m dostupu do resursu: https://zakon.rada.gov.ua/laws/show/1060-12\#Text]. 
9. Kamins`ka Ye. I. Derzhavno-gromads`ke upravlinnya $\mathrm{v}$ zagal`noosvitn`omu navchal nomu zakladi / Ye. I. Kamins`ka. X. : Vy`d. gr. «Osnova», 2013. 112 s.

10. Komarny`cz`ky`j M. S. Derzhavno-gromads`ka sy`stema upravlinnya osvitoyu. Aspekty`samovryaduvannya. 2000. \# 3. S. 34-35.

11. Lebid`Ye. Derzhavno-gromads`ky`j ty`p upravlinnya osvitoyu: yevropejs`ky`j dosvid ta ukrayins`ki realiyi [Elektronny`j resurs] / Ye. Lebid. Rezhy`m dostupu :HYPER/www.europexxi.kiev.ua

13. Pastovens`ky`j O.V. Gromads`ko-derzhavne upravlinnya zagal`noyu seredn`oyu osvitoyu v regioni: dy`s.... d-ra ped. nauk: 13.00.06. Ky`yiv. 2015. 438 s.

12. Nacional`na doktry`na rozvy`tku osvity`Ukrayiny`u XXI stolitti. K: «Shkil`ny`j svit», 2001.

14. Pro osvitu: Zakon Ukrayiny`vid 5 veresnya 2017 roku \# 2145-VIII. URL: https://zakon.rada.gov.ua/laws/show/2145-19/print.

15. Fedorova N.M. Stanovleny`e gosudarstvenno-obshhestvennogo upravleny`ya shkol`num obrazovany`em v Rossy`y’: dy`s....d-ra ped. nauk: specz. 13.00.01. SPb. 2010. $466 \mathrm{~s}$.

16. Franko I. Nashi narodni shkoly` i yix potreby`. Zibrannya tvoriv u 50 t. Ky`yiv: Naukova dumka, 1986.T. 46, Kn. 2, S. 96-97. 